\title{
Priorities for Conservation and Sustainable Use of Forest Genetic Resources in Four Mexican Pines
}

\author{
Andrés Flores ${ }^{1,2}{ }^{\oplus}$, Javier López-Upton ${ }^{3}{ }^{\circledR}$, Cristobal D. Rullán-Silva ${ }^{4}$, Adriana E. Olthoff ${ }^{5}$, \\ Ricardo Alía ${ }^{2,6}$ (D), Cuauhtémoc Sáenz-Romero ${ }^{7}$ (1) and José M. Garcia del Barrio ${ }^{2,6, *}$ \\ 1 CENID-COMEF, National Institute for Forestry, Agriculture and Livestock Research, Progreso 5, \\ Coyoacán 04010, Mexico \\ 2 Research Institute on Sustainable Forest Management, University of Valladolid, Av. Madrid s/n, \\ 34004 Palencia, Spain \\ 3 Colegio de Postgraduados, Postgrado en Ciencias Forestales, Km 36.5 Carr. Mexico-Texcoco, \\ Montecillo 56230, Mexico \\ 4 División Académica de Ciencias Biológicas. Universidad Juárez Autónoma deTabasco. Ctra. \\ Villahermosa-Cárdenas, km 0.5, Centro, Tabasco 86000, Mexico \\ 5 Freelance, Villahermosa, Tabasco 86000, Mexico \\ 6 INIA-CIFOR, Department of Ecology and Forest Genetics, Ctra. Coruña km 7.5, 28040 Madrid, Spain \\ 7 Instituto de Investigaciones Agropecuarias y Forestales, Universidad Michoacana de San Nicolás de Hidalgo. \\ Av. San Juanito Itzícuaro s/n, Col. Nueva Esperanza, Morelia 58337, Mexico \\ * Correspondence: jmgarcia@inia.es; Tel.: +34-91347-6858
}

Received: 22 July 2019; Accepted: 4 August 2019; Published: 9 August 2019

\begin{abstract}
The strategies for the conservation and sustainable use of forest genetic resources, which are essential for the future adaptation of forest species to changing environments, are also a source of valuable genetic resources for breeding and restoration activities. The first step to define and implement cost-effective strategies is to identify specific priority populations. Mexico, in spite of being characterized by high levels of tree species diversity, mostly lacks a combined strategy for the genetic conservation and use of forest genetic resources. The aims of this work are: (i) to identify areas for gene conservation, and (ii) to propose measures for the conservation and sustainable use of forest genetic resources of four pine species: Pinus greggii Engelm. ex Parl., Pinus oocarpa Schiede ex Schltdl., Pinus patula Schiede ex Schltdl. \& Cham. and Pinus pseudostrobus Lindl. To do that, we use the existing information on the distribution, genetic variation and conservation and breeding efforts in Mexico. Overall, 51 areas for establishing genetic conservation units were prioritized and 6 genetic zones for the use of forest genetic resources in breeding and selection of forest reproductive material were identified. The current conservation efforts for the four priority Mexican pines should be improved to satisfy the needs of a national breeding and conservation network.
\end{abstract}

Keywords: genetic diversity; genetic conservation units; forest management; Pinus greggii; Pinus oocarpa; Pinus patula; Pinus pseudostrobus

\section{Introduction}

Forests are essential for the maintenance of biological diversity in terrestrial ecosystems and provide a wide range of goods and services, including genetic resources that are not only indispensable now but also constitute a unique and irreplaceable reserve for the future. However, large perturbation events (e.g., climatic change) or activities from either outside of the forestry sector (e.g., industrial activities, land use changes, etc.) or inside of it (e.g., forest management, seed transfer, etc.) affect, or can affect in the near future, the genetic diversity of species and their distribution over space and 
time. Therefore, actions have been requested at the global scale [1] for the conservation and sustainable use of forest genetic resources.

Forest tree species are long lived and widely distributed, with a typically low degree of domestication and remarkable phenotypic and genetic differences in important traits among populations, despite high levels of gene flow [2]. These differences are essential both for breeding, i.e., provenances or seed sources to be used for plantations [3], and for conservation programs whose main objective is intra-specific genetic diversity [4]. However, conservation and a sustainable use of forest genetic resources have not always been considered as part of the same strategy [5].

Genetic conservation priorities are based on the economic and environmental importance of a species, its ecological functions, or other features that contribute to its relevance and/or its level of risk [6]. Although genetic studies of forest tree species have increased enormously throughout this century [7], we still lack information for many of them, and decisions are mostly made in the absence of any genetic knowledge [8].

A "bioregion" approach has been extensively used when planning and implementing the marketing of genetic resources—deployment and procurement zones [9]—and conservation of genetic resources-genetic zones [10]. In the latter, environmental zones have been used as surrogates in different conservation programs [11,12], operating under the assumption that they are areas in which many tree species have a similar genetic background.

From a landscape-level perspective, breeding or planting activities may affect the conservation of genetic resources [13] either positively, by increasing population adaptability [14], or negatively, by favoring introgression with non-adapted materials or substitution with more productive materials [15]. Eventually, these actions can affect the functioning of the ecosystem, and make it unable to provide the environmental services of the original, now replaced ([16,17]). In contrast, an adequate conservation of existing resources can provide additional sources of diversity for future breeding programs.

Practical forestry experience suggests that a sound management of genetic resources must include conservation efforts based on two overlapping strategies: a management of natural forests that pays due respect to their genetic resources, and the establishment of networks of smaller geneconservation areas [11].

Mexican pines are a good case study for prioritizing areas for both conservation and the sustainable use of genetic resources in the absence of complete genetic information. Mexico is one of the genus Pinus diversity centers, presenting 49 out of the 120 species of pines in the world [18], many of which are actively managed. Sixty percent of them are of commercial and industrial importance, providing timber, resin and pulp [19], but they also constitute a valuable source of genetic resources [20]. Despite the importance of Mexican forest trees and their genetic resources, genetic studies are rare, barely covering $1.2 \%$ of Mexican species, and 58\% of those corresponding to Pinus [21]. The level of Mexican pine species' genetic knowledge is, in most cases, clearly incomplete.

We have selected four species, Pinus greggii Engelm. ex Parl. (including var. greggii and var. australis Donahue \& Lopez), Pinus oocarpa Schiede ex Schltdl., Pinus patula Schiede ex Schltdl. \& Cham. (var. patula and var. longipedunculata Loock ex Martínez) and P. pseudostrobus Lindl. They present contrasting distribution ranges and levels of importance [22] for timber production [19], the sawmill industry and resin production [23], and they are also present in commercial plantations [24]. These species have been planted in different continents, e.g., P. oocarpa in Europe, Asia, Africa, America and Oceania, or P. patula in Africa $[25,26]$. These species are also considered highly valuable for ex situ gene conservation, i.e., gene conservation banks and genetic tests [20,25].

The aims of this work are: (i) to identify priority areas for gene conservation, and (ii) to propose measures for the conservation and sustainable use of P. greggii, P. oocarpa, P. patula and P. pseudostrobus genetic resources. Firstly, we identify the most relevant existing information related to the identification and characterization of their genetic resources. We use information concerning the distribution range of the species and the delimitation of germplasm transfer zones, the conservation of forest tree species 
in protected areas and the sustainable use of forest genetic resources (germplasm production units, or populations used at different stages in breeding). We then check for gaps, taking into account the distribution area and the genetic zones of the species, and we prioritize areas to improve the status of conservation and sustainable use of forest genetic resources in the considered species.

\section{Materials and Methods}

\subsection{Data Sources}

Four Mexican pine species were selected for the study: P. greggii (var. greggii and var. australis), P. oocarpa, P. patula (var. patula and var. longipedunculata) and P. pseudostrobus. These species are distributed along different temperate mountain ranges (Figure 1) as pure and mixed coniferous forests and pine-oak forests, in a wide altitudinal range (600-3000 m a.s.l.) (Supplementary Materials Table S1).

We defined the native distribution range of the species using the National Forest and Land Inventory (NFLI, 2004 to 2007 [27]), which covers Mexico in a systematic stratified random sampling with a grid of $5 \mathrm{~km}$ (Figure 1). We removed those plots considered plantations [28], or of non-native origin (based on our own knowledge).

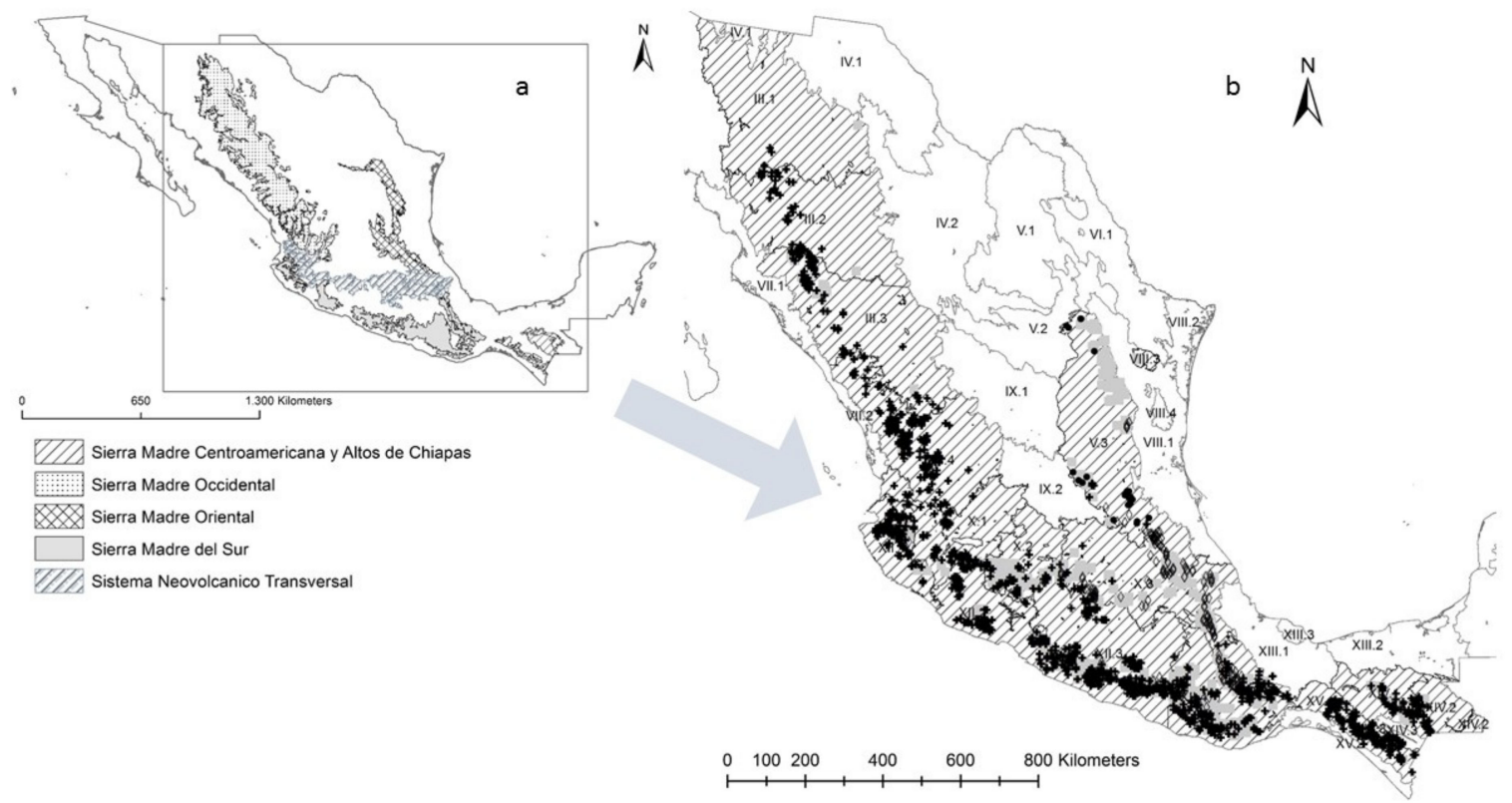

Figure 1. (a) Mexican territory with the five "sierras". (b) Native distribution of Pinus greggi Engelm. ex Parl. (black dots), P. oocarpa Schiede ex Schltdl. (black crosses), P. patula Schiede ex Schltdl. \& Cham. (unfilled diamonds) and P. pseudostrobus Lindl. (grey squares) in Mexico modified from the NFLI (see Material and Methods), and germplasm transfer zones (contour grey solid lines [29]. Striped germplasm transfer zones are indicative of the presence of at least one of the four pine species.

\subsection{Genetic Zones}

The existing genetic studies the four species (Supplementary Materials Figure S1, [30]) do not allow for a precise definition of genetic zones, so we have used the germplasm transfer zones (equivalent to seed zones) as a proxy. Seed zones are areas with similar ecological and climatic characteristics that harbor populations with relatively uniform genotypic or phenotypic characteristics [29,31-33]. Mexico has been divided into 41 germplasm transfer zones by the Mexican National Forest Commission (CONAFOR by its Spanish acronym) (Figure 1 and Supplementary Materials Table S2). The genetic zones for each of the four pines were obtained by overlapping their distribution and the germplasm transfer zones. Genetic zones with less than 20 trees for a given species according to the NFLI 
were excluded from subsequent analysis, as it would be difficult to identify populations suited for conservation or seed collection.

\subsection{Conservation Units}

We considered a set of minimum requirements for defining Gene Conservation Units (GCUs) (modified from [11] on Supplementary Materials Table S3) by taking into consideration population size, type of management, monitoring and ownership.

The objective was to select at least one genetic conservation unit per genetic zone and species, except in cases of fragmented distribution (e.g., high distance $(>50 \mathrm{~km})$ between population cores, or existing barriers to gene flow within the region), in which case one gene conservation unit was selected from each patch (or up to 3, depending on the genetic zone). The main criteria for the selection of GCUs were: population size, genetic information availability, dynamic genetic conservation management, and public ownership. In all cases, we prioritized extensive and centered populations in the genetic zone or patch. Then, among all the populations included in a given genetic zone (or patch, in the case of the fragmented ones), we considered first those populations characterized in genetic studies and/or provenance or progeny trials. These populations have been chosen for germplasm collection by genetic experts and, therefore, are good candidates in terms of population size and representation within the area. When we did not manage to cover the required number of GCUs, we chose populations among the areas protected for biodiversity conservation, as their type of management (i.e., dynamic genetic conservation) was compatible with the conservation objective for all types of protected areas established by the Mexican Commission for Biodiversity (CONABIO, information for 2016 available at http://www.gob.mx/conabio). If the needs for a given region were not yet fulfilled, we chose populations situated in private forests. The georeferenced information was mapped using Arc-GIS 10.5 [34].

\subsection{Use of Genetics Resources}

We measured the importance of a genetic zone for the use of genetic resources, based on the presence of germplasm production units (seed stands and seed orchards). We assumed that the investment in the establishment and maintenance of such production units is an indication of the species' economic relevance in the area. We also used information from the existing material in genetic trials, i.e., provenance and progeny tests, established by different institutions (Supplementary Materials Figure S1, [30]), as they provide information about populations identified for the selection of forest reproductive material with well-known genetic backgrounds. As these populations have been evaluated, different genetic information is available from papers and reports.

\subsection{Importance of Genetic Zones for the Conservation and Sustainable Use of Forest Genetic Resources}

Using the previous information, for each genetic zone of the three species studied we collected: the number of trees sampled by the NFLI $\left(\mathrm{n}_{\mathrm{i}}\right)$, the number of populations with molecular data $\left(\mathrm{n}_{\mathrm{mk}}\right)$, the number of populations with seed stands (seed stand plus seed area) $\left(\mathrm{n}_{\mathrm{st}}\right)$, the number of individuals selected for progeny tests $\left(n_{i s}\right)$, the number of populations present in provenance tests $\left(n_{p t}\right)$ and the number of seed orchards $\left(n_{s o}\right)$. Finally, we calculated the number of GCUs $\left(n_{g}\right)$.

The importance of the pine species for timber production was calculated using the official timber production [35] and plantation statistics [36] collected state by state, which did not include disaggregation by pine species. We made a proportional assignment to each genetic zone using as a basis the distribution of the four species and those harbored in genetic zones. A similar approach was followed for the plantation areas. We then estimated productivity and degradation areas based on the land zoning established by the National Forest Commission [37].

Based on this information, expert knowledge and the recommendations established by the papers or reports previously analyzed, we defined a value for conservation and a value for breeding for the different genetic zones of the species in a subjective scale from 1 to 4 , with 4 being the highest priority. 
As a final step we assessed the status of each species using indicators derived and adapted from the EUFORGEN program [38] (Table 1).

Table 1. Indicators of the genetic zones in conservation and management of genetic resources.

\begin{tabular}{ccc}
\hline & Indicator & Description \\
\hline I1 & Number of genetic zones & Number of genetic zones with presence of the species \\
I2 & Molecular characterization effort & $\%$ of genetic zones with at least 1 sample in molecular studies \\
I3 & Provenance characterization effort & $\%$ of genetic zones with at least 1 population in provenance test \\
I4 & Progeny characterization effort & $\%$ of genetic zones with plus trees in progeny tests \\
I5 & Seed stands index & $\%$ of genetic zones with at least 1 forest seed production units \\
I6 & Seed orchard index & $\%$ of genetic zones with at least 1 seed orchard \\
I7 & Genetic conservation index & $\%$ of genetic zones with at least 1 conservation units identified \\
\hline
\end{tabular}

\section{Results}

\subsection{Genetic Zones}

Sixteen genetic zones, in which at least one of the four pine species was effectively present, were identified over the 41 seed zones: four zones included one species, seven included two species, three zones included three species and two included four species (Figure 2). Pinus oocarpa had the most widespread representation (15 genetic zones), followed by P. pseudostrobus (13 genetic zones). In contrast, P. patula (5 genetic zones) and P. greggii (2 genetic zones) had a more restricted distribution.

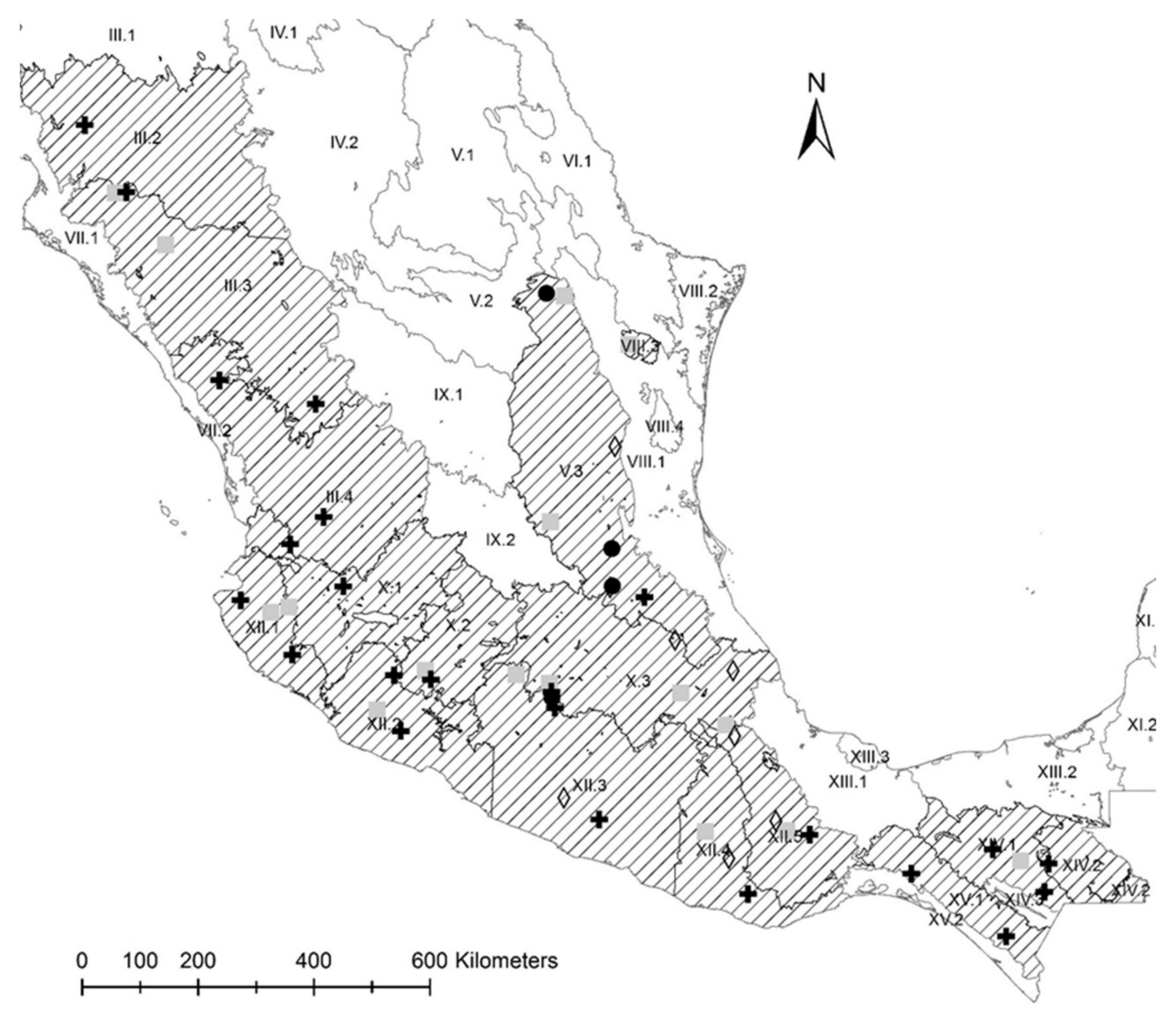

Figure 2. Conservation units proposed by genetic zones (striped polygons) for four Mexican pine species: Pinus greggi (black dots), P. oocarpa (black crosses), P. patula (unfilled diamonds) and P. pseudostrobus (grey squares). 


\subsection{Conservation Units}

We identified a total of 51 areas for establishing GCUs for the target species (Figure 2 and Supplemetary Materials Table S4): 16 for P. pseudostrobus, 23 for P. oocarpa, 8 for P. patula and 4 for P. greggii. In relation to the selection criteria, nearly $60 \%$ of the GCUs were chosen in areas with existing genetic information. In the absence of genetic information, the other $35 \%$ of the GCUs were located in protected areas situated in public lands, and $5 \%$ in private forests.

\subsection{Use of Genetic Resources}

Breeding and characterization efforts were quite different depending on the species and region (Table 2). Characterization (both molecular and in genetic trials) was limited to some of the areas, and differed among species. The efforts aiming at the use of forest reproductive material had been quite reduced. In all of the cases, the activities were of low intensity and mostly consisted of the selection of seed stands. All the species presented many gaps, with many regions lacking sources of identified forest reproductive material that could be considered local.

\subsection{Efforts for Conservation and Use of Genetic Resources}

The efforts for the conservation, characterization and use of forest genetic resources in the four Mexican pines, as quantified by 7 indicators (Table 3), were clearly insufficient. Most of the genetic zones still did not have enough data for the characterization of forest genetic resources or even seed production. P. patula was the only species that had seen seed orchards established (I6 $>0$ ). In terms of molecular characterization efforts, $P$. oocarpa and P. greggii had been the object of more efforts than P. patula or P. pseudostrobus (I2). P. greggii and P. patula had seen more generalized provenance (I3) and progeny (I4) characterization efforts than the other species, with indicator values of 0 or near 0 . Although P. greggii had more forest reproductive material production units than the rest the species, it covered just a few states and was meant to help timber production.

\subsection{Prioritization of Regions for Conservation and Use of Genetic Resources in Mexico}

It was possible to identify important regions for the use of genetic resources. The Jalisco and Oaxaca regions (X.1, XII.1, XII.2 and XII.4 and XII.5, respectively) were important in terms of forest productivity and pine wood production. Other genetic zones presented high forest productivity (III.2, III.3 and III.4), with a potentiality for land afforestation (III.2 and III.3). Afforestation or forest restoration were necessary also in V.3, X.3, XIV.1 and XV.1, and in more reduced areas of other mentioned genetic zones where soil degradation (III.2, V.3, XII.2 and XII.3) or severe erosion (XII.2, XII.3 and XII.4) could affect forest suitability.

Based on the available information, six genetic zones (V.3, X.2, X.3, XII.3, XII.4 and XII.5) were defined as the most suitable sources of germplasm for use in commercial plantations (Figure 3) for three of the pine species studied (the exception was P. pseudostrobus). These areas also presented the highest potential for conservation and breeding. Two of these zones were targeted for conservation and use of the four pines species (V.3 and X.3). Although they were not the genetic zones with the greatest number of trees inventoried, they were the most diverse in the number of species and the ones where the actions dedicated to the conservation and use of genetic resources were more intensive (see Table 4). 
Table 2. Conservation efforts and use of genetic resources by genetic zone and species (PS: P. pseudsotrobus Lindl., OC: P. oocarpa Schiede ex Schltdl., PA: P. patula Schiede ex Schltdl. \& Cham., GR: P. greggii Engelm. ex Parl.)

\begin{tabular}{|c|c|c|c|c|c|c|c|c|c|c|c|c|c|c|c|c|c|c|c|c|c|c|c|c|c|c|c|c|}
\hline \multirow[t]{2}{*}{$\begin{array}{l}\text { Genetic } \\
\text { Zone }\end{array}$} & \multicolumn{4}{|c|}{$\begin{array}{l}\text { Trees National Forest Inventory } \\
\qquad\left(\mathrm{n}_{\mathrm{i}}\right)\end{array}$} & \multicolumn{4}{|c|}{$\begin{array}{c}\text { Molecular Characterization } \\
\left(\mathrm{n}_{\mathrm{mk}}\right)\end{array}$} & \multicolumn{4}{|c|}{$\begin{array}{l}\text { Seed Stands } \\
\left(\mathrm{n}_{\mathrm{st}}\right)\end{array}$} & \multicolumn{5}{|c|}{$\begin{array}{c}\text { Progeny Testing } \\
\left(\mathrm{n}_{\mathrm{is}}\right)\end{array}$} & \multicolumn{4}{|c|}{$\begin{array}{c}\text { Provenance Testing } \\
\left(\mathrm{n}_{\mathrm{pt}}\right)\end{array}$} & \multicolumn{3}{|c|}{$\begin{array}{c}\text { Seed Orchards } \\
\left(\mathbf{n}_{\text {so }}\right)\end{array}$} & \multicolumn{4}{|c|}{$\begin{array}{c}\text { Gene Conservation } \\
\text { Units }\left(n_{\mathrm{g}}\right)\end{array}$} \\
\hline & PS & OC & PA & GR & PS & OC & PA & GR & PS & OC & PA & GR & PS & OC & PA & GR & PS & OC & PA & GR & PS & OC & PA & GR & PS & OC & PA & GR \\
\hline III.2 & 55 & 587 & - & - & 0 & 1 & - & - & 0 & 0 & - & - & 0 & 0 & - & - & 0 & 0 & - & - & 0 & 0 & - & - & 1 & 1 & - & - \\
\hline III.3 & 199 & 593 & - & - & 0 & 1 & - & - & 0 & 1 & - & - & 0 & 0 & - & - & 0 & 0 & - & - & 0 & 0 & - & - & 1 & 2 & - & - \\
\hline III.4 & - & 1201 & - & - & - & 3 & - & - & - & 1 & - & - & - & 0 & - & - & - & 0 & - & - & - & 0 & - & - & - & 2 & - & - \\
\hline V.3 & 1136 & 56 & 538 & 308 & 0 & 2 & 3 & 19 & 1 & 0 & 0 & 0 & 0 & 0 & 0 & 0 & 0 & 0 & 5 & 22 & 0 & 0 & 0 & 0 & 2 & 1 & 2 & 3 \\
\hline VIII.3 & 27 & - & - & - & 0 & - & - & - & 0 & - & - & - & 0 & - & - & - & 0 & - & - & - & 0 & - & - & - & 1 & - & - & - \\
\hline X.1 & 61 & 699 & - & - & 0 & 1 & - & - & 0 & 0 & - & - & 0 & 0 & - & - & 0 & 0 & - & - & 0 & 0 & - & - & 1 & 2 & - & - \\
\hline X.2 & 777 & 581 & 126 & - & 2 & 8 & 0 & - & 2 & 1 & 0 & - & 13 & 0 & 0 & - & 0 & 5 & 0 & - & 0 & 5 & 0 & - & 1 & 1 & 0 & - \\
\hline X.3 & 1262 & 177 & 1028 & 23 & 4 & 2 & 1 & 0 & 8 & 0 & 5 & 0 & 0 & 0 & 36 & 120 & 0 & 0 & 4 & 2 & 0 & 0 & 1 & 0 & 2 & 1 & 2 & 1 \\
\hline XII.1 & 240 & 1222 & - & - & 0 & 1 & - & - & 0 & 0 & - & - & 0 & 0 & - & - & 0 & 0 & - & - & 0 & 0 & - & - & 1 & 2 & - & - \\
\hline XII.2 & 268 & 1503 & - & - & 1 & 1 & - & - & 1 & 2 & - & - & 0 & 0 & - & - & 0 & 0 & - & - & 0 & 0 & - & - & 1 & 2 & - & - \\
\hline XII.3 & 608 & 2650 & 81 & - & 1 & 2 & 1 & - & 0 & 2 & 0 & - & 0 & 0 & 0 & - & 0 & 0 & 0 & - & 0 & 0 & 0 & - & 1 & 2 & 1 & - \\
\hline XII.4 & 1944 & 1534 & 66 & - & 0 & 1 & 0 & - & 0 & 0 & 0 & - & 0 & 0 & 0 & - & 0 & 0 & 0 & - & 0 & 0 & 0 & - & 1 & 1 & 1 & - \\
\hline XII.5 & 1122 & 924 & 820 & - & 0 & 0 & 7 & - & 1 & 0 & 0 & - & 0 & 0 & 0 & - & 0 & 0 & 0 & - & 0 & 0 & 0 & - & 2 & 1 & 2 & - \\
\hline XIV.1 & 88 & 404 & - & - & 1 & 4 & - & - & 1 & 0 & - & - & 0 & 0 & - & - & 0 & 0 & - & - & 0 & 0 & - & - & 1 & 2 & - & - \\
\hline XIV.2 & - & 312 & - & - & - & 0 & - & - & - & 0 & - & - & - & 0 & - & - & - & 0 & - & - & - & 0 & - & - & - & 1 & - & - \\
\hline XV.1 & - & 1123 & - & - & - & 3 & - & - & - & 1 & - & - & - & 0 & - & - & - & 0 & - & - & - & 0 & - & - & - & 2 & - & - \\
\hline Total & 7787 & 13566 & 2659 & 331 & 9 & 30 & 12 & 19 & 14 & 8 & 5 & 0 & 13 & 0 & 36 & 120 & 0 & 5 & 9 & 24 & 0 & 0 & 1 & 0 & 16 & 23 & 8 & 4 \\
\hline
\end{tabular}

$\mathrm{n}_{\mathrm{i}}$ : number of trees sampled by the NFLI, $\mathrm{n}_{\mathrm{mk}}$ : number of populations per zone with molecular data, $\mathrm{n}_{\mathrm{st}}:$ number of populations with seed stands, $\mathrm{n}_{\mathrm{is}}:$ number of 
Table 3. Indicators for the target species.

\begin{tabular}{cccccc}
\hline & Indicator & P. pseudostrobus & P. oocarpa & P. patula & P. greggii \\
\hline I1 & Number genetic zones & 13 & 15 & 6 & 2 \\
I2 & Molecular characterization effort & 38.46 & 86.66 & 66.66 & 50.00 \\
I3 & Provenance characterization effort & 0.00 & 6.66 & 33.33 & 100.00 \\
I4 & Progeny characterization effort & 7.69 & 0.00 & 16.66 & 50.00 \\
I3 & Seed stands index & 46.15 & 40.00 & 16.66 & 0.00 \\
I6 & Seed orchard index & 0.00 & 0.00 & 16.66 & 0.00 \\
I7 & Genetic conservation index * & 100.00 & 100.00 & 83.33 & 100.00 \\
\hline
\end{tabular}

* Based on GCUs proposed for each species (see Table S4).

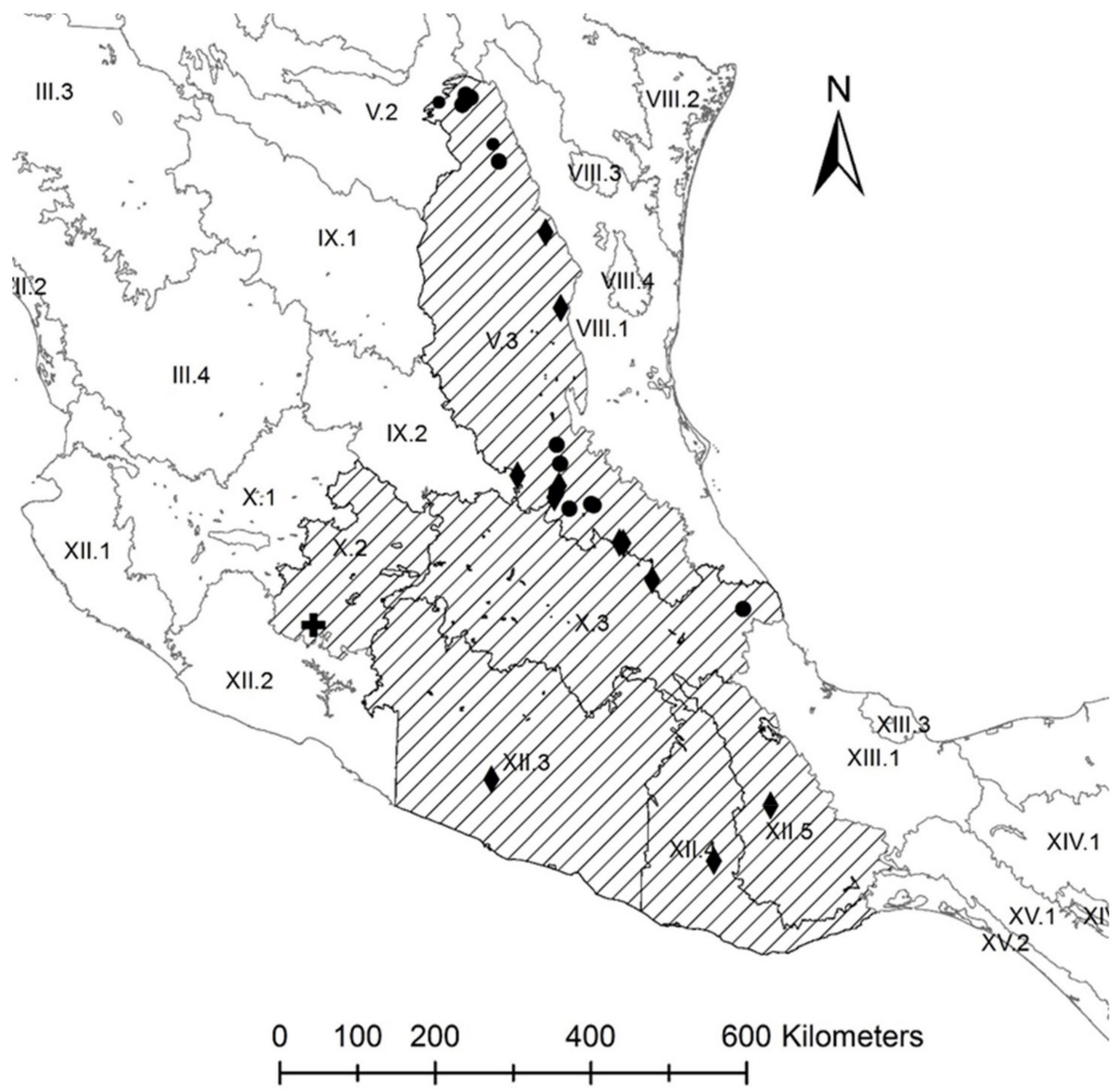

Figure 3. Populations and their genetic zones (striped polygons) considered as the most suitable source for providing forest reproductive material. Pinus greggi (black dots), P. oocarpa (black crosses) and P. patula (black diamonds). 
Table 4. Importance for conservation and use of forest genetic resources by genetic zone and species (PS: P. pseudsotrobus, OC: P. oocarpa, PA: P. patula, GR: P. greggii).

\begin{tabular}{cccccccccc}
\hline $\begin{array}{c}\text { Genetic } \\
\text { Zone }\end{array}$ & $\begin{array}{c}\text { Presence of the } \\
\text { Pine Species }\end{array}$ & \multicolumn{3}{c}{$\begin{array}{c}\text { Value for Conservation } \\
\mathbf{( 1} \text { to } \mathbf{4})\end{array}$} & \multicolumn{5}{c}{$\begin{array}{c}\text { Value for Breeding } \\
\text { (1 to 4) }\end{array}$} \\
\hline & & PS & OC & PA & GR & PS & OC & PA & GR \\
\hline III.2 & 50 & 4 & 2 & - & - & 1 & 2 & - & - \\
III.3 & 88 & 3 & 2 & - & - & 2 & 2 & - & - \\
III.4 & 137 & - & 2 & - & - & - & 3 & - & - \\
V.3 & 143 & 1 & 4 & 4 & 4 & 3 & 1 & 4 & 4 \\
VIII.3 & 2 & 4 & - & - & - & 1 & - & - & - \\
X.1 & 66 & 3 & 2 & - & - & 1 & 2 & - & - \\
X.2 & 66 & 2 & 4 & 2 & - & 3 & 4 & 2 & - \\
X.3 & 144 & 1 & 4 & 4 & 4 & 3 & 1 & 4 & 4 \\
XII.1 & 93 & 3 & 2 & - & - & 2 & 3 & - & - \\
XII.2 & 114 & 3 & 2 & - & - & 2 & 3 & - & - \\
XII.3 & 300 & 2 & 2 & 4 & - & 2 & 3 & 4 & - \\
XII.4 & 213 & 1 & 2 & 4 & - & 3 & 3 & 4 & - \\
XII.5 & 188 & 1 & 2 & 4 & - & 3 & 3 & 4 & - \\
XIV.1 & 60 & 4 & 3 & - & - & 1 & 2 & - & - \\
XIV.2 & 18 & - & 3 & - & - & - & 2 & - & - \\
XV.1 & 109 & - & 2 & - & - & - & 3 & - & - \\
\hline
\end{tabular}

\section{Discussion}

We have identified some priority zones in order to help advance conservation efforts and the use of forest genetic resources in four Mexican pine species. Using forest germplasm transfer zones, defined by [29] as a proxy for genetic zones, we identified 51 areas for delimiting conservation units into 16 genetic zones. Also, based on the existing data, we considered that six of the genetic zones could be the most suitable sources of forest reproductive material to use in these species' afforestation, restoration or replanting actions.

One of our main targets was to integrate conservation and sustainable use of forest resources in Mexican forest management. As of the time of this paper, Mexico's main national conservation program (defined as CONABIO) [39] does not include forest tree species, which is one of the main limitations curtailing the implementation of any long-term activities in the region. The promotion of conservation areas $[40,41]$ is further justified by the prediction, by 2050, of important species area reductions (50.4\% for P. oocarpa, $23.4 \%$ for P. patula and $12.8 \%$ for P. pseudostrobus) [39]. However, neither the governmental authorities nor the nongovernmental agencies have set in situ conservation actions ex professo to face the projected climatic change impacts. Our proposal for the conservation of genetic resources is the establishment in the region of an efficient network in terms of number of units and coverage.

This proposal, as it consists mainly of conservation units located in public lands, could benefit from a cooperation between community groups and the state and federal governments aimed at overcoming one of the main problems of conservation, i.e., its perception, in some cases, by rural societies as an unfair governmental imposition, resulting in frequent changes in land use and forest deterioration [42].

Our definition of genetic zones based on germplasm transfer zones is conservative in the sense that populations in the same region that might differ genetically have not been included. For neutral or nearly neutral markers, most Mexican pine species, as most of the species in the genus, present high levels of genetic diversity and relatively low genetic differentiation among populations [21]. Exceptions such as P. greggii [43,44], which present low levels of diversity, are also compatible with our definition of genetic zones. For adaptive traits, e.g., growth potential and frost resistance, P. oocarpa shows high genetic diversity [21]. Most of the studied Mexican conifer species have shown high genetic differentiation among populations along altitudinal gradients, such as Pinus oocarpa [45-50]. 
Also, there are significant differences among close populations for P. greggii [24,51], P. oocarpa, P. patula and P. pseudostrobus [52]. Therefore, transferring germplasm need to consider the patterning of genetic differentiation among populations for adaptive quantitative traits.

Protected areas alone do not fulfill all specific requirements for the conservation of forest genetic resources [53]. We have also relied on existing information to identify priority areas for the selection of GCUs. These areas can be affected by illegal extraction of various forest products (e.g., logging or conversion of forest timber into charcoal [54]), or other factors that impede genetic conservation in the long term. The management plan of the areas should include [55]: (a) an explicit objective for genetic resource maintenance; (b) an estimation of population size and demography; (c) a protocol for providing information on and access to the genetic resources and, finally, (d) a monitor for the conservation status of the populations [56], as part a of a national genetic resources information system.

On the present papery, we have not considered ex situ conservation measures, which are nonetheless important in the context of climate change [57-59]. That would take the form of selecting sites that could in the future potentially become similar to the contemporary climatic habitat of the priority species and, therefore, serve as germplasm sources under the projected future (likely warmer and drier) climate.

Indicators for the use of forest reproductive material show that most of the activities should be based on low-input strategies, disregarding the economic importance of the species [60], and not on intensive (and costly) breeding programs that cover only some species [20]. These strategies could be applied in a small number of regions and would allow for the production of local genetic resources for use in forest management activities. These activities are also compatible with in situ conservation. These low-input activities would benefit the local communities, who are the main stakeholders [61]. Most of the forested land in Mexico (75\%) is under collective tenure, and more than $50 \%$ of all collective holdings are forest communities [42], which are able to implement low-cost breeding and conservation activities.

The quality of forest reproductive material used in plantations can be improved by setting specific objectives in breeding activities, especially to reduce seedling mortality (at present $14 \%$ caused by frost damage and $66 \%$ by drought $[58,62])$, to improve origin identification ( $33 \%$ of of the current seeds are from an unknown origin [62]) and intraspecific taxa identification (e.g., P. pseudostrobus [63]) ant to improve adaptation to local environmental and climatic conditions [64].

\section{Conclusions}

We have identified genetic zones and areas for delimiting GCUs in four important Mexican pine species, and defined different actions for their conservation and sustainable use in the country. The number of areas proposed was different among species and relied on the minimum requirements that must be followed for conservation. Seed procurement zones were the hub of our conservation proposal in order to ensure known genotypic or phenotypic characteristics for the conservations units. Further genetic studies on the species would be necessary to continue advancing in the conservation and use of genetic resources in the long term. We found that the efforts to use forest reproductive material are limited and mainly focused on forest germplasm production units (seed stands and seed areas). Actions must be initiated to improve the use and conservation of genetic resources, mainly in order to address the challenges imposed by the current climatic changes and the pressure for change in land use for agriculture, grazing and urban development.

Supplementary Materials: The following are available online at http://www.mdpi.com/1999-4907/10/8/675/s1, Figure S1: Location of populations selected for genetic diversity (triangles), provenance tests (stars) and progeny tests (circles), and location of tests sites for provenances (big circle with filled star inside) and progenies (big circle with filled star inside) for the four selected pines, Table S1: General climatic and edaphic patterns of target species, Table S2: Physiographic Provinces (PS) and Germplasm Transfer Zones (GTZ), Table S3: Minimum requirements for genetic conservation units, Table S4: Proposed Conservation Units for P. greggii, P. oocarpa, P. patula and P. pseudostrobus. References List Online Supplementary Materials. 
Author Contributions: A.F., R.A. and J.M.G.d.B.: conceived and design the research; J.L.-U.: contributed materials; A.F., J.M.G.d.B., C.D.R.-S. and A.E.O. analyzed the data; A.F., R.A., J.M.G.d.B. and C.S.-R.: wrote the paper; C.S.-R.: provided meaningful guidance during the development of the study.

Funding: A.F. was supported by a grant from the Mexico's National Council for Science and Technology (CONACyT) and National Institute for Forestry, Agricultural and Livestock Research (INIFAP). R.A. and J.M.G.d.B. supported by the Project AEG 17-048 established in the frame of the measure 15.2 "support to the conservation and use of forest genetic resources" and under Regulation (EU) No 1305/2013 of the European Parliament and of the Council of 17 December 2013 on support for rural development by the European Agricultural Fund for Rural Development (EAFRD) with $75 \%$ co-financing. No other external funding was implied.

Acknowledgments: We are grateful to the National Forest Commission (CONAFOR) by NFLI data and information supplied.

Conflicts of Interest: The authors declare no conflict of interest.

\section{References}

1. FAO. The State of the World's Forest Genetics Resources; FAO: Rome, Italy, 2014; ISBN 978-92-5-108403-8.

2. Savolainen, O.; Pyhäjärvi, T.; Knürr, T. Gene flow and local adaptation in trees. Annu. Rev. Ecol. Evol. Syst. 2007, 38, 595-619. [CrossRef]

3. Konnert, M.; Fady, B.; An Gömöry, D.; A’hara, S.; Wolter, F.; Ducci, F.; Koskela, J.; Bozzano, M.; Maaten, T.; Kowalczyk, J. Use and Transfer of Forest Reproductive Material in Europe in the Context of Climate Change; European Forest Genetic Resources Programme (EUFORGEN), Bioversity International: Rome, Italy, 2015; ISBN 9789292550318.

4. De Vries, S.M.G.; Alan, M.; Bozzano, M.; Burianek, V.; Collin, E.; Cottrell, J.; Ivankovic, M.; Kelleher, C.T.; Koskela, J.; Rotach, P.; et al. Pan-European Strategy for Genetic Conservation of Forest Trees and Establishment of a Core Network of Dynamic Conservation Units; European Forest Genetic Resources Programme (EUFORGEN), Bioversity International: Rome, Italy, 2015; ISBN 9789292550295.

5. Jiménez, P.; Diaz-Fernandez, P.M.; Iglesias, S.; Prada, M.A.; Garcia del Barrio, J.M.; Alba, N.; Alía, R.; Díaz-Fernández, P.M.; Iglesias, S.; Prada, A.; et al. Strategy for the Conservation and Sustainable Use of Spanish Forest Genetic Resources. For. Syst. 2009, 18, 13-19. [CrossRef]

6. Rajora, O.P.; Mosseler, A. Challenges and opportunities for conservation of forest genetic resources. Euphytica 2001, 118, 197-212. [CrossRef]

7. Alberto, F.J.; Aitken, S.N.; Alía, R.; González-Martínez, S.C.; Hänninen, H.; Kremer, A.; Lefèvre, F.; Lenormand, T.; Yeaman, S.; Whetten, R.; et al. Potential for evolutionary responses to climate change-Evidence from tree populations. Glob. Chang. Biol. 2013, 19, 1645-1661. [CrossRef] [PubMed]

8. Eriksson, G.; Namkoong, G.; Roberds, J.H. Dynamic gene conservation for uncertain futures. For. Ecol. Manag. 1993, 62, 15-37. [CrossRef]

9. Van Buijtenen, J.P. Fundamental genetic principles. In Handbook of Quantitative Forest Genetics; Fins, L., Friedman, S., Brotschol, J., Eds.; Springer: Dordrecht, The Netherlands, 1992; pp. 29-68, ISBN 978-90-481-4112-8.

10. Kanowski, P. In situ forest conservation: A broader vision for the 21 st century. In In Situ and EX Situ Conservation of Commercial Tropical Trees; Gadjah Mada University and ITTO: Yogyakarta, Indonesia, 2001; pp. 11-36. ISBN 9799665205.

11. Koskela, J.; Lefèvre, F.; Schueler, S.; Kraigher, H.; Olrik, D.C.; Hubert, J.; Longauer, R.; Bozzano, M.; Yrjänä, L.; Alizoti, P.; et al. Translating conservation genetics into management: Pan-European minimum requirements for dynamic conservation units of forest tree genetic diversity. Biol. Conserv. 2013, 157, 39-49. [CrossRef]

12. Hamann, A.; Smets, P.; Yanchuk, A.D.; Aitken, S.N. An ecogeographic framework for in situ conservation of forest trees in British Columbia. Can. J. For. Res. 2005, 35, 2553-2561. [CrossRef]

13. Yanchuk, A.D. Techniques in forest tree breeding. In Forests and Forest Plants; Owens, J.N., Lund, H.G., Eds.; EOLSS Publications: Oxford, UK, 2009; Volume 3, pp. 40-47. ISBN 9781905839407.

14. Prober, S.M.; Byrne, M.; Mclean, E.H.; Steane, D.A.; Potts, B.M.; Vaillancourt, R.E. Climate-adjusted provenancing: A strategy for climate-resilient ecological restoration. Front. Ecol. Evol. 2015, 3, 65. [CrossRef]

15. Koskela, J.; Vinceti, B.; Dvorak, W.; Bush, D.; Dawson, I.K.; Loo, J.; Kjaer, E.D.; Navarro, C.; Padolina, C.; Bordács, S.; et al. Utilization and transfer of forest genetic resources: A global review. For. Ecol. Manag. 2014, 333, 22-34. [CrossRef] 
16. Rymer, L. Pine plantations in australia as a habitat for native animals. Environ. Conserv. 1981, 8, 95-96. [CrossRef]

17. Ehrlich, P.R.; Mooney, H.A. Extinction, substitution, and ecosystem services. Bioscience 1983, 33, $248-254$. [CrossRef]

18. Gernandt, D.S.; Pérez-de la Rosa, J.A. Biodiversidad de Pinophyta (coníferas) en México. Rev. Mex. Biodivers. 2014, 85, 126-133. [CrossRef]

19. Sánchez-González, A. Una visión actual de la diversidad y distribución de los pinos de México. Madera Bosques 2008, 14, 107-120. [CrossRef]

20. Dvorak, W.S. CAMCORE: Industry and governments' efforts to conserve threatened forest species in Guatemala, Honduras and Mexico. For. Ecol. Manag. 1990, 35, 151-157. [CrossRef]

21. Wehenkel, C.; Del Rocío Mariscal-Lucero, S.; Jaramillo-Correa, J.P.; López-Sánchez, C.A.; Vargas-Hernández, J.J.; Sáenz-Romero, C. Genetic diversity and conservation of Mexican forest trees. In Biodiversity and Conservation of Woody Plants; Ahuja, M., Jain, S., Eds.; Sustainable Development and Biodiversity; Springer International Publishing: Cham, Switzerland, 2017; Volume 17, pp. 37-67, ISBN 9783642209246.

22. Perry, J.P. The Pines of Mexico and Central America; Timber Press, Inc.: Portland, OR, USA, 1991; ISBN 0881921742.

23. Fuentes López, M.E.; García Salazar, J.A.; Hernández Martínez, J. Factores que afectan el mercado de madera aserrada de pino en México. Madera Bosques 2006, 12, 17-28. [CrossRef]

24. López-Upton, J.; Donahue, J.K.; Plascencia-Escalante, F.O.; Ramírez-Herrera, C. Provenance variation in growth characters of four subtropical pine species planted in Mexico. New For. 2005, 29, 1-13. [CrossRef]

25. Dvorak, W. The strategic importance of applied tree conservation programs to the forest industry in South Africa. South. For. J. For. Sci. 2012, 74, 1-6. [CrossRef]

26. Gwaze, D.P.; Dungey, H.S.; Dieters, M.J.; Toon, P.G.; Nikles, D.G. Interspecific pine hybrids. I. Genetic parameter estimates in Australia. For. Genet. 2000, 7, 11-20.

27. CONAFOR Inventario Nacional Forestal y de Suelo (INFyS) 2013-2014, 32 volume collection. Available online: http://transparencia01.cnf.gob.mx/OpenData/Inventario// (accessed on 2 January 2018).

28. CONAFOR Inventario Nacional Forestal y de Suelos. Informe 2004-2009. Available online: https://www.snieg.mx/DocumentacionPortal/iin/acuerdo_3_X/Manual_y_Procedimientos_para_el_Muestreo_de_ Campo_INFyS_2004-2009.pdf (accessed on 2 January 2018).

29. CONAFOR. Manual Para el Establecimiento de Unidades Productoras de Germoplasma Forestal; CONAFOR: Zapopan, Mexico, 2016.

30. Flores, A. Phenotypic Variation among Natural Populations of Pines: Implications for the Management and Conservation of Genetic Resources. Ph.D. Thesis, Universidad de Valladolid, Valladolid, Spain, 2018.

31. Secretaria de Economía Declaratoria de vigencia de la Norma Mexicana NMX-AA-169-SCFI-2016. Available online: http://dof.gob.mx/nota_detalle.php?codigo $=5455455 \& f e c h a=03 / 10 / 2016$ (accessed on 3 November 2017).

32. Flores Flores, C.; López-Upton, J.; Valencia Manzo, S. Manual Técnico Para el Establecimiento de Ensayos de Procedencias y Progenies; CONAFOR: Zapopan, Mexico, 2014.

33. Ledig, F.T. The Conservation of Diversity in Forest Trees. Bioscience 1988, 38, 471-479. [CrossRef]

34. ESRI ArcGIS Desktop: Release 10. 2011. Available online: http://desktop.arcgis.com/es/arcmap/ (accessed on 10 June 2019).

35. INEGI Mexico National Institute of Statistics, Geography and Informatics. Available online: https://www. inegi.org.mx/ (accessed on 11 January 2018).

36. SEMARNAT Plantation area. Available online: https://datos.gob.mx/busca/dataset/indicadores-basicos-deldesempeno-ambiental--recursos-forestales (accessed on 2 January 2018).

37. CONAFOR Zonificación forestal. Available online: https://snigf.cnf.gob.mx/zonificacion/ (accessed on 1 January 2018).

38. EUFORGEN. Revised indicator on genetic resources (4.6) of the pan-European criteria and indicators for sustainable forest management. REPORT of EUFORGEN working group. Unpublished work, 2019.

39. Villers-Ruiz, L.; Trejo-Vázquez, I. Impacto del cambio climático en los bosques y áreas naturales protegidas de México. Interciencia 1998, 23, 10-19. 
40. Rojas-Soto, O.R.; Sosa, V.; Ornelas, J.F. Forecasting cloud forest in eastern and southern Mexico: Conservation insights under future climate change scenarios. Biodivers. Conserv. 2012, 21, 2671-2690. [CrossRef]

41. Sáenz-Romero, C.; Snively, A.E.; Lindig-Cisneros, R. Conservation and restoration of pine forest genetic resources in México. Silvae Genet. 2003, 52, 233-237.

42. Merino-Perez, L. Community action for conservation: Mexican experiences. In Community Action for Conservation: Mexican Experiences; Porter-Bolland, L., Ruiz-Mallén, I., Camacho-Benavides, C., McCandless, S.R., Eds.; Springer Science \& Business Media: New York, NY, USA, 2013; pp. 25-44, ISBN 9781461479567.

43. Parraguirre, L.C.; Vargas, H.J.J.; Ramírez, V.P.; Azpíroz, R.H.S.; Jasso, M.J. Estructura de la diversidad Genética en poblaciones naturales de Pinus greggü Engelm. Rev. Fitotec. Mex. 2002, 25, $279-287$.

44. Hernández-Velasco, J.; Hernández-Díaz, J.C.; Fladung, M.; Cañadas-López, Á.; Prieto-Ruíz, J.Á.; Wehenkel, C. Spatial genetic structure in four Pinus species in the Sierra. Can. J. For. Res. 2017, 47, 73-80. [CrossRef]

45. Sáenz-Romero, C.; Guzmán-Reyna, R.R.; Rehfeldt, G.E. Altitudinal genetic variation among Pinus oocarpa populations in Michoacán, Mexico. For. Ecol. Manag. 2006, 229, 340-350. [CrossRef]

46. Viveros-Viveros, H.; Sáenz-Romero, C.; Vargas-Hernández, J.J.; López-Upton, J.; Ramírez-Valverde, G.; Santacruz-Varela, A. Altitudinal genetic variation in Pinus hartwegii Lindl I: Height growth, shoot phenology, and frost damage in seedlings. For. Ecol. Manag. 2009, 257, 836-842. [CrossRef]

47. Sáenz-Romero, C.; Rehfeldt, G.E.; Soto-Correa, J.C.; Aguilar-Aguilar, S.; Zamarripa-Morales, V.; López-Upton, J. Altitudinal genetic variation among Pinus pseudostrobus populations from Michoacán, México. Two location shadehouse test results. Rev. Fitotec. Mex. 2012, 35, 111-120.

48. Loya-Rebollar, E.; Sáenz-Romero, C.; Lindig-Cisneros, R.A.; Lobit, P.; Villegas-Moreno, J.A.; Sánchez-Vargas, N.M. Clinal variation in Pinus hartwegii populations and its application for adaptation to climate change. Silvae Genet. 2013, 62, 86-95. [CrossRef]

49. Ruiz-Talonia, L.F.; Sánchez-Vargas, N.M.; Bayuelo-Jiménez, J.S.; Lara-Cabrera, S.I.; Sáenz-Romero, C. Altitudinal genetic variation among native Pinus patula provenances: Performance in two locations, seed zone delineation and adaptation to climate change. Silvae Genet. 2014, 63, 139-149. [CrossRef]

50. Ortiz-Bibian, M.A.; Blanco-García, A.; Lindig-Cisneros, R.A.; Gómez-Romero, M.; Castellanos-Acuña, D.; Herrerías-Diego, Y.; Sánchez-Vargas, N.M.; Sáenz-Romero, C. Genetic variation in Abies religiosa for quantitative traits and delineation of elevational and climatic zoning for maintaining monarch butterfly overwintering sites in Mexico, considering climatic change. Silvae Genet. 2017, 66, 14-23. [CrossRef]

51. Ramírez-Herrera, C.; Vargas-Hernández, J.J.; López-Upton, J. Distribución y conservación de las poblaciones naturales de Pinus greggii. Acta Botánica Mex. 2005, 72, 1-16. [CrossRef]

52. Flores, A.; Climent, J.; Pando, V.; López-Upton, J.; Alía, R. Intraspecific variation in pines from the Trans-Mexican Volcanic Belt grown under two watering regimes: Implications for management of genetic resources. Forests 2018, 9, 71. [CrossRef]

53. Koski, V.; Skrøppa, T.; Paule, L.; Wolf, H.; Turok, J. Technical Guidelines for Genetic Conservation of Norway Spruce (Picea Abies (L.) Karst.); International Plant Genetic Resources Institute: Rome, Italy, 1997; ISBN 92-9043-331-X.

54. Wallace, J.; Aquilué, N.; Archambault, C.; Carpentier, S.; Francoeur, X.; Greffard, M.H.; Laforest, I.; Galicia, L.; Messier, C. Present forest management structures and policies in temperate forests of Mexico: Challenges and prospects for unique tree species assemblages. For. Chron. 2015, 91, 306-317. [CrossRef]

55. National Research Council In situ Conservation of Genetic Resources. Managing Global Genetic Resources: Agricultural Crop Issues and Policies; The National Academies Press: Washington, DC, USA, 1993; p. 451, ISBN 978-0-309-04430-1.

56. Aravanopoulos, F.A. Conservation and monitoring of tree genetic resources in temperate forests. Curr. For. Rep. 2016, 2, 119-129. [CrossRef]

57. Sáenz-Romero, C.; Rehfeldt, G.E.; Crookston, N.L.; Duval, P.; St-Amant, R.; Beaulieu, J.; Richardson, B.A. Spline models of contemporary, 2030, 2060 and 2090 climates for Mexico and their use in understanding climate-change impacts on the vegetation. Clim. Chang. 2010, 102, 595-623. [CrossRef]

58. Sáenz-Romero, C.; Lindig-Cisneros, R.A.; Joyce, D.G.; Beaulieu, J.; Clair, J.B.S.; Jaquish, B.C. Assisted migration of forest populations for adapting trees to climate change. Rev. Chapingo Ser. Cienc. For. Ambiente 2016, 22, 303-323. 
59. Castellanos-Acuña, D.; Vance-Borland, K.W.; Clair, J.B.S.; Hamann, A.; López-Upton, J.; Gómez-Pineda, E.; Ortega-Rodríguez, J.M.; Sáenz-Romero, C. Climate-based seed zones for Mexico: Guiding reforestation under observed and projected climate change. New For. 2017, 49, 297-309. [CrossRef]

60. El-Kassaby, Y.A.; Lstiburek, M. Breeding without Breeding. Genet. Res. 2009, 91, 111-120. [CrossRef]

61. Sáenz-Romero, C.; Tapia-Olivares, B.L. Genetic variation in frost damage and seed zone delineation within an altitudinal transect of Pinus devoniana (P. michoacana) in Mexico. Silvae Genet. 2008, 57, 165-170. [CrossRef]

62. Burney, O.; Aldrete, A.; Alvarez Reyes, R.; Prieto Ruíz, J.A.; Sánchez Velazquez, J.R.; Mexal, J.G. Mexico-addressing challenges to reforestation. J. For. 2015, 113, 404-413. [CrossRef]

63. Sáenz-Romero, C.; Lindig-Cisneros, R. Evaluación y propuestas para el programa de reforestación en Michoacán. Cienc. Nicolatta 2004, 37, 107-122.

64. Stead, J.W.; Styles, B.T. Studies of Central American pines: A revision of the 'pseudostrobus' group (Pinaceae). Bot. J. Linn. Soc. 1984, 89, 249-275. [CrossRef]

(C) 2019 by the authors. Licensee MDPI, Basel, Switzerland. This article is an open access article distributed under the terms and conditions of the Creative Commons Attribution (CC BY) license (http://creativecommons.org/licenses/by/4.0/). 